\title{
Visitors' satisfaction and development strategy of agrotourism: evidence from Semarang, Indonesia
}

\author{
Raras Sekar Kinasih", Wiludjeng Roessali and Edy Prasetyo \\ Faculty of Animal and Agricultural Sciences, Diponegoro University, Semarang, Indonesia \\ *Correspondence email: rskinasih@gmail.com
}

\section{ARTICLE INFO}

- Research Article

Article History

Received 3 July 2020

Accepted 28 July 2020

Published 31 October 2020

\section{Keywords}

agrotourism; development strategy; marketing mix; satisfaction

JEL Classification Q13; R58; Z32

\begin{abstract}
Visitor satisfaction is fascinating to learn because this is always a significant positioning in developing tourism destination. This study aims to analyze visitor satisfaction and formulate the agrotourism development strategy. The research survey was conducted in Purwosari Agrotourism, Mijen District, Semarang City, Indonesia. A total of 100 visitors and 20 people were purposively selected to address research objective. Visitor satisfaction is evaluated using the 7P marketing mix approach. The analysis method uses the Importance Performance Analysis and Customer Satisfaction Index to analyze visitor satisfaction; and Strength, Weakness, Opportunity, and Threat (SWOT) analysis to formulate development strategy. The results showed the location, transportation, promotion, and physical evidence (parking area, toilets, and information boards) are the main priority attributes of improvement. The response of visitors was in the satisfied category with a total Satisfaction Index of $73.39 \%$. The development strategy of Purwosari Agrotourism shows the SO (strength and opportunity) strategy approach, which means being in a favorable position with aggressive strategy recommendations. The strategy includes the innovation of tourism products, collaboration with other tourism objects to create tour packages, and expand product marketing networks.
\end{abstract}

Citation: Kinasih, R. S., Roessali, W., \& Prasetyo, E. (2020). Visitors' satisfaction and development strategy of agrotourism: evidence from Semarang, Indonesia. Journal of Socioeconomics and Development, 3(2), 101-114. https://doi.org/10.31328/jsed.v3i2.1450

ISSN 2615-6075 online; ISSN 2615-6946 print CUWG Press, 2020

\section{INTRODUCTION}

Tourism at the international and national level continues to experience growth. This can be seen from the statistical calculations for 2017-2019 which show that the contribution of tourism to Indonesia's GDP increased from $4.11 \% ; 4.50 \%$ to $4.80 \%$ (Kementrian Pariwisata dan Ekonomi Kreatif, 2019). Today, tourism development offers many new destinations with unique concepts that can attract tourists to visit (Budiasa, 2011). Nature tourism is one of the type of tourism that always attracts tourist from various ages such as agrotourism. The concept of agrotourism is utilizing natural resources with the main attraction such as beautiful natural scenery and nuances of beauty. The definition of agrotourism according to Sznajder et al. (2009) is a recreation that brings tourists to agricultural or farm area with tourist services for recreational, educational, and entertainment purposes. Agrotourism can provide food, beverage, rooms, ranch activity, and sport activity. Agrotourism is a combination of tourism and agriculture. The existence of agrotourism has many positive impacts on social and economic aspects corresponding to increasing more job opportunities 
as well as the community income and local ownsource revenue. Cooperation between agriculture and tourism is one of the steps undertaken to create new jobs, improving the living standards of the local, creating a sustainable economy, and forming a potential market for local agricultural products (Han et al., 2020). The community relation is also getting along in harmony. Accordingly, it is important to do development by focusing on the image of agrotourism that is closely related to local potential and culture (Utama \& Junaedi, 2019). According to Nugroho et al. (2018), planning at the local level of tourism need a quality management service, participation, and empowerment of the local people. This includes efforts of (i) developing of infrastructure to meet environmental conservation, (ii) building governance to gain a positive experience and well-being, (iii) integrating the tourism promotion through the product development and market segmentation, and (v) interpreting to offer the education of cultural and environmental conservation. Meanwhile, Prasetyo \& Hariani (2018) state that farmers have contributed to advancing the agrotourism in Batu, with the role to continue to grow the services and intensity for managing demand from outside the region.

Attractions with the agriculture theme in the city of Semarang also experienced growth. Semarang city agriculture office is the main institution in the effort to develop agrotourism by carrying out the development of two of the four planned agrotourism programs. The first agrotourism going under the name Cepoko agrotourism was inaugurated in 2017, which then continued with the opening of the second agrotourism in early 2019, i.e. Purwosari. Purwosari agrotourism offers attractions in various products such as fruit orchards, flower gardens, hydroponic vegetables, and greenhouse plants. This agrotourism officially began operating in 2019 and has received various visits from schools to institutions, or the visit of a state official. According to the manager, Purwosari agrotourism has not been widely known by the public because of no intense marketing activities. Thus, the number of visitors is relatively small compared to Cepoko agrotourism. Data in November 2019 were only 385 people in Purwosari agrotourism while visitors in Cepoko agrotourism were 1,111 people.

Purwosari agrotourism requires an appropriate marketing strategy to introduce this agrotourism to the wider community. For marketing activities to run well and fulfilling the market target, the company or organization can identify the needs and expectations of consumers (Perreault, McCarthy, \& Cannon, 2006). The identification can be done by examining the visitors' experience of the products and services offered. The positive experience of tourists on the products, services, and other resources offered can provide opportunities for attractions to bring in potential tourist visits (Elvera, 2020). This can happen because of the recommendations by word of mouth that are often used as a reference for people to have decisions to visit. Tourism development requires an appropriate marketing mix strategy $7 \mathrm{P}$ (product, price, place, promotion, people, process, and physical evidence) because of tourism offering products and services (Lisarini \& Ningtyas, 2014). The results of the study from the visitors' side can be used as ideas in determining development plans that can be applied in the future. According to Fitrianti et al. (2015), the development of attributes of a tourist attraction is done by looking at the attribute needs of visitors so it will achieve high satisfaction.

The purpose of this study is to analyze visitors' satisfaction based on 7P marketing mix variables (product, price, place, promotion, people, process, and physical evidence) and formulate the Purwosari agrotourism development strategy.

\section{RESEARCH METHOD}

The research was conducted in Purwosari agrotourism, Mijen district, Semarang City between January to March 2020. The site selection was done deliberately with the consideration that Purwosari agrotourism is the second agrotourism recently developed by the Ministry of Agriculture, Government of Indonesia. This study further expected to imply the marketing management and development of Purwosari agrotourism.

The study was conducted by the survey method with the interview to respondents of agrotourism visitors. The respondent sample determined by nonprobability sampling with accidental sampling and quota sampling techniques. Accidental sampling is a technique of taking samples spontaneously or coincidentally so that anyone met and following research needs selected as a respondent. The determination of the number of samples refers to quota sampling. The number of samples was 
determined first followed by the criteria of respondents. The quota sampling was chosen because the number of samples could not be determined through a formula if the population or sampling frame was unknown (Juliandi et al., 2014). The respondents were 100 visitors who are more than 17 years old that came to Purwosari agrotourism. The visitors were assumed to have the capability to give opinion and judgment about the destination.

In the second research objective, the research sample used a non-probability sampling approach with a purposive sampling technique. The selection of subjects is adjusted to the required qualifications or research objectives. Data collection in this study used key persons of 20 people. They consisted of two employees of Purwosari agrotourism Office Technical Implementation Unit (UPTD), two employees from UPTD of agriculture service garden, two people managing the agrotourism estate, two leaders of surrounding community, two community members and 10 other people are agrotourism visitors.

Data collection used interview technique, questionnaires, and observations. Attributes to the questionnaire questions totaled 30 items on a closed questionnaire for satisfaction analysis and open for the development strategy.

Analysis of visitor satisfaction can be measured by the Importance Performance Analysis (IPA) and Customer Satisfaction Index (CSI) approaches. IPA is an analysis that aims to determine the extent of visitors' expectation or importance and the assessment of agrotourism performance. IPA will show the level of conformity (Tki) which is a score comparison of the performance evaluation attribute to $\mathrm{i}(\mathrm{Xi})$ with the importance of attribute to i (Yi). The average level of performance is

$$
X i=\Sigma X i / n
$$

and the importance level of

$$
\mathrm{Yi}=\mathrm{Yi} / \mathrm{n}
$$

which $\mathrm{n}$ is the number of respondents. The importance and performance of each attribute are then illustrated in a Cartesian diagram consisting of four quadrants. The value of the X-axis (horizontal) is the average performance and the $\mathrm{Y}$-axis (vertical) is the average of importance which is then compared with $k$, namely the number of factors that affect visitors' satisfaction.

The next analysis is CSI which aims to measure satisfaction in percent. The measurement phase of the analysis is according to Anggraeni et al. (2015): (i) calculating the weighted factor (weighted importance factor) by making the average value of the importance in percent units; (ii) calculate the weighted score (TWS), which is the product of the average performance value of each attribute and the importance weighting factor of each attribute; (iii) calculate the weighted total or total weighted of all attributes; (iv) calculate the satisfaction index by means of a total weighted score divided by a maximum scale of 5 and multiplied by $100 \%$; (v) see overall satisfaction in the CSI scale table (very satisfied $=81-100 \%)$, (satisfied $=66-80.99 \%)$, (quite satisfied $=51-65.99 \%$ ), (less satisfied $=35$ $50.99 \%$ ), and (not satisfied $=0-34.99 \%$ ).

The preliminary development strategy formulation used an explorative approach with a SWOT analysis method by having depth interview with the keypersons. SWOT analysis is a method that analyses strengths, weaknesses, opportunities, and threats of agrotourism which are then used in the form of Internal Factor Analysis Summary (IFAS) tables and External Factor Analysis Summary (EFAS). Determination of strengths, weaknesses, opportunities, and threats based on the theory in the book and supported by in-depth interviews with agrotourism managers.

The strengths are largely the uniqueness of nature and culture or human creation and good road access. Weaknesses generally come from human resources. Opportunities can be obtained from government commitments; the increasing trend of agrotourism and tourist attraction. Threats can come through competition with other tourist objects and low accessibility. The results of the total score in the IFAS-EFAS table are then used in making a SWOT analysis diagram that determines where the position of agrotourism is. The coordinate $X$ and $Y$ were obtained from the strength-weakness and the opportunity-threat score, respectively. The SWOT diagram divides the position of agrotourism into four quadrants. Quadrant I describes a favorable situation, agrotourism can use its strengths and opportunities. Quadrant II represents that agrotourism faces threats but it has internal strength. Quadrant III shows that agrotourism faces 
enormous opportunities and internal weaknesses at the same time. Quadrant IV indicates a very unfavorable situation where there are various internal threats and weaknesses. SWOT analysis matrix provides four alternative possible strategies namely Strength-Opportunity (SO), Weakness-Opportunity (WO), Strength-Threat (ST), Weakness-Threat (WT) strategies.

\section{RESULT AND DISCUSSION}

\section{Characteristics of Respondents}

Characteristics of respondents are divided into five categories of characteristics namely age, sex, place of residence, last education, occupation and income level (Table 1).

Table 1. Characteristics of Respondents

\begin{tabular}{lr}
\hline Variable & People $^{\mathrm{a}}$ \\
\hline Age & \\
$18-27$ years & 30 \\
$28-37$ years & 18 \\
$38-47$ years & 14 \\
$48-57$ years & 27 \\
$58-67$ years & 10 \\
$\geq 68$ years & 1 \\
Gender & \\
Female & 54 \\
Male & 46 \\
Place of Residence & \\
Semarang City & 77 \\
Semarang Regency & 1 \\
Outside Semarang Area & 18 \\
Outside Central Java & 4 \\
Education & \\
Elementary School & 2 \\
Junior High School & 6 \\
Senior High School & 48 \\
College & 43 \\
Other & 1 \\
Occupation & \\
Student & 14 \\
Employee & 23 \\
Civil Servant & 12 \\
Private Enterprise & 18 \\
Other & 33 \\
Income per month & 7 \\
<1.0 million rupiahs & \\
1.0 - 2.9 million rupiahs & 30 \\
3.0- 4.9 million rupiahs & \\
>5.0 million rupiahs & 28 \\
Have no income yet & 22 \\
\hline Sample size 100 respondent & 13 \\
\hline
\end{tabular}

asample size 100 respondent

Based on the research that has been done, it is known that the majority of visitors aged between 1827 years with several 30 people (30\%). The majority of the next age visitors are in the age range 48-57 years as many as 27 people (27\%). The highest number of ages shows that visitors who come can be said to be classified as the young generation, so some traits tend to prefer to explore or like trying new things. The second-highest number is visitors with an age range of 48-57years. Handayani (2016) stated that young people are highly interested in educational tourism because they have a strong enough drive to satisfy curiosity and explore various aspects when traveling.

The distribution of visitors by sex has a percentage that can be said to be quite balanced, namely 54 women (54\%) and 46 men (46\%). These results indicated that visiting a tourist attraction is one of the ways to fulfill people's needs and it can maintain people's mental health (Cheng, Jin, \& Wong, 2014). The criteria by the respondent residence, the visitors mostly came from the city of Semarang with 77 people (77\%).

The distribution of visitors when viewed from the level of education, the majority are high school education (SMA) as many as 48 people (48\%). Higher Education places the second-highest percentage with a total of 43 people (43\%). The criteria by the type of working visitors, the majority is who works in a private company as an employee of 23 people $(23 \%) .18$ people $(18 \%)$ visitors are entrepreneurs and 18 people (18\%) visitors are housewives. The majority income level of visitors is in the range of one million to 2.9 million rupiahs per month with a total of 30 people (30\%) and followed by at the range of three million to 4.9 million rupiahs with a total of 28 people ( $28 \%$ ).

\section{Importance - Performance Analysis}

Measurement of Importance Performance Analysis (IPA) aims to see the level of assessment of the performance of agrotourism and the importance level of visitors in the form of scores. Overall attributes, the suitability level has a total percentage of $81.54 \%$. A more detailed explanation can be seen in Table 2.

Conformity level (Tki) is a value that describes the level of visitor satisfaction with a particular attribute. The high percentage results show that there is little difference between the value of importance and performance, so it can be said that visitors are satisfied with the performance of agrotourism because it has approached the level of 
importance. Fitrianti et al. (2015) says that the high percentage of the conformity level is directly proportional to visitor satisfaction. Thus, the higher the level of conformity, the higher the satisfaction of the attribute. A low level of conformity occurs because of the difference between performance and importance. Therefore, the less difference between the performance score with the importance, the higher the level of suitability. Overall, the suitability level values for all attributes showed an average of $81.54 \%$. According to Iswari et al. (2015), the level of conformity that is said to be good is when the value exceeds the average value of the suitability level to close to $100 \%$.

Table 2. The Results of The Calculation of Performance Appraisals and Visitor Importance

\begin{tabular}{|c|c|c|c|c|c|c|c|}
\hline \multirow{2}{*}{$\begin{array}{l}\text { Marketing } \\
\text { Mix }\end{array}$} & \multirow{2}{*}{ No } & \multirow{2}{*}{ Indicator } & \multirow{2}{*}{$\begin{array}{c}\mathrm{Xi} \\
\text { (score) }\end{array}$} & \multirow{2}{*}{$\begin{array}{c}\text { Yi } \\
\text { (score) }\end{array}$} & \multirow{2}{*}{$\begin{array}{l}\text { Tki } \\
(\%)\end{array}$} & \multicolumn{2}{|c|}{ Average } \\
\hline & & & & & & $\mathrm{Xi}$ & $\mathrm{Yi}$ \\
\hline \multirow[t]{4}{*}{ Product } & 1 & Purwosari agrotourism has various types of fruit & 379 & 446 & 84.98 & 3.79 & 4.46 \\
\hline & 2 & The size of guava fruit is medium & 401 & 413 & 97.09 & 4.01 & 4.13 \\
\hline & 3 & The texture of guava fruit is crunchy & 377 & 420 & 89.76 & 3.77 & 4.20 \\
\hline & 4 & Crystal guava fruit has a sweet taste & 367 & 471 & 77.92 & 3.67 & 4.71 \\
\hline \multirow[t]{4}{*}{ Price } & 5 & Affordable fruit prices (budget $\geq$ prices) & 391 & 439 & 89.07 & 3.91 & 4.39 \\
\hline & 6 & The price of fruit match with the quality & 377 & 454 & 83.04 & 3.77 & 4.54 \\
\hline & 7 & $\begin{array}{l}\text { Fruit prices are affordable from other places ( } \leq 15 \text { thousand } \\
\text { rupiahs) }\end{array}$ & 325 & 425 & 76.47 & 3.25 & 4.25 \\
\hline & 8 & Visitors get the bonus or discounted price for fruit purchases & 306 & 440 & 69.55 & 3.06 & 4.40 \\
\hline \multirow[t]{4}{*}{ Place } & 9 & Agrotourism location is strategic (close to the main road) & 313 & 463 & 67.60 & 3.13 & 4.63 \\
\hline & 10 & $\begin{array}{l}\text { Agrotourism can be visited by large/small buses, public } \\
\text { transportation, private vehicles, online transportation }\end{array}$ & 362 & 464 & 78.02 & 3.62 & 4.64 \\
\hline & 11 & Road condition to the location is smooth and wide & 330 & 457 & 72.21 & 3.30 & 4.57 \\
\hline & 12 & $\begin{array}{l}\text { Agrotourism is located in the side of the road and there is } \\
\text { available signpost }\end{array}$ & 351 & 454 & 77.31 & 3.51 & 4.54 \\
\hline \multirow[t]{4}{*}{ Promotion } & 13 & $\begin{array}{l}\text { Agrotourism uses } 5 \text { aspects of promotion (sales promotion, } \\
\text { advertising, human resources, public relation, direct sales) }\end{array}$ & 329 & 464 & 70.91 & 3.29 & 4.64 \\
\hline & 14 & $\begin{array}{l}\text { The Purwosari agrotourism uses print media, online media } \\
\text { (website) and social media (Facebook, Instagram, line, twitter) } \\
\text { for promotion activity }\end{array}$ & 333 & 448 & 74.33 & 3.33 & 4.48 \\
\hline & 15 & $\begin{array}{l}\text { The information about this Agrotourism is available on online } \\
\text { news sites and google maps }\end{array}$ & 378 & 445 & 84.94 & 3.78 & 4.45 \\
\hline & 16 & $\begin{array}{l}\text { Direct fruit picking tourist facilities is equipped with complete } \\
\text { tools (cutter, basket, bamboo cap) }\end{array}$ & 347 & 463 & 74.95 & 3.47 & 4.63 \\
\hline \multirow[t]{4}{*}{ People } & 17 & Staff performance (friendly, polite, neat) & 422 & 461 & 91.54 & 4.22 & 4.61 \\
\hline & 18 & The speed and alertness of officers is fast & 418 & 455 & 91.87 & 4.18 & 4.55 \\
\hline & 19 & The staffs are able to be interactive, informative, conversant & 408 & 452 & 90.27 & 4.08 & 4.52 \\
\hline & 20 & $\begin{array}{l}\text { Staffs' information on booking procedures and agrotourism is } \\
\text { clear }\end{array}$ & 418 & 457 & 91.47 & 4.18 & 4.57 \\
\hline \multirow[t]{4}{*}{ Process } & 21 & The tours are suitable for what they offered & 369 & 444 & 83.11 & 3.69 & 4.44 \\
\hline & 22 & Agrotourism entry procedures are easy (no entry fee) & 407 & 427 & 95.32 & 4.07 & 4.27 \\
\hline & 23 & Fruit payment is easy and fast & 387 & 457 & 84.68 & 3.87 & 4.57 \\
\hline & 24 & Place booking procedures is easy (by telephone) & 356 & 440 & 80.91 & 3.56 & 4.40 \\
\hline \multirow[t]{7}{*}{$\begin{array}{l}\text { Physical } \\
\text { Evidence }\end{array}$} & 25 & $\begin{array}{l}\text { Parking space can accommodate big or small buses, cars, the } \\
\text { motorcycle also surface textures shall be stable, anti-slip and } \\
\text { shall have hard surfaces (paving/concrete/asphalt) }\end{array}$ & 360 & 468 & 76.92 & 3.60 & 4.68 \\
\hline & 26 & The toilet is clean and comfortable & 353 & 467 & 75.59 & 3.53 & 4.67 \\
\hline & 27 & The rubbish bin is easy to find & 368 & 464 & 79.31 & 3.68 & 4.64 \\
\hline & 28 & $\begin{array}{l}\text { Worship facility is feasible (provide ablution place, prayer tools, } \\
\text { footwear) }\end{array}$ & 373 & 463 & 80.56 & 3.73 & 4.63 \\
\hline & 29 & Directions sign at agrotourism is available & 334 & 459 & 72.77 & 3.34 & 4.59 \\
\hline & 30 & Plant info board is easy to find & 374 & 446 & 83.86 & 3.74 & 4.46 \\
\hline & & Average & & & 81.54 & 3.67 & 4.51 \\
\hline
\end{tabular}

Table 2 shows 7P variables (product, price, place, promotion, people, process, physical evidence) can represent indicator attributes that need priority to be improved. In the product variable, the fruit flavor gets the lowest suitability value $(77.92 \%)$ so it needs the manager's attention. Based on the 
research in the field, several visitors stated that the crystal guava products were relatively less sweet. According to the manager, seasonal factors such as rainfall can affect the taste of crystal guava.

Meanwhile, fruit price discounts or purchase bonuses on variable prices need attention. The opening price of crystal guava fruit is 15 thousand rupiahs per $\mathrm{kg}$. For the purchases of at least $5 \mathrm{~kg}$, buyers will get a discount price of 12.5 thousand rupiahs per $\mathrm{kg}$. The place variable becomes an important attribute to consider the agrotourism location. Purwosari agrotourism is located not too close to the main road so that agrotourism visitors certainly need a personal transport mode to reach the location. The availability of public transportation needs to be considered for tourists who do not have private vehicles. Chin et al. (2018) stated that one of the important factors that can influence the decision to visit a tourist attraction is the availability, affordability, and convenience of transportation or accessibility to tourist sites. The amenity will increase the opportunity of a higher visit to a tourist destination. Febinanda et al. (2018) said that tourist satisfaction is significantly influenced by price variable. However, it is not affected by the destination image and amenity.

The promotion method variable is an attribute that must be transformed immediately in the Purwosari agrotourism. The management already has a correct concept but needs to be supported by allout promotion to bring in more visitors to come. Today, the online promotion approach is widely used by businesses organizations. The promotion of tourism objects is an important part of the planning and developing a tourist destination in the region (Nugroho et al., 2018). Adhanisa \& Fatchiya (2017) stated that promotion using online media is now a very promising way that makes it easier for people to communicate and interact for developing promotional activities.

In the people variable, staff interaction and knowledge are attributes that must be improved even though the overall suitability level of this variable is on average above $90 \%$. According to (Setiawan, 2016), the success of the tourism industry cannot be separated from the role of skilled and knowledgeable workers both in quality and quantity. In the process variable, an attribute that must be considered is the ease of the procedure for ordering a place by visitors. Physical evidence variables display important attributes for space management at tourist sites related to indicators such as direction signs to the parking area, entrances, offices or information desks, gardens and flower gardens, etc.

The next analysis is to show which attributes become the main priorities for improving tourism management concerning the 7 variables using the Cartesian diagram. The diagram shows the mapping of importance and performance relation which are divided into four quadrants (Figure 1).

The main priorities (quadrant I) in increasing visitor satisfaction in the Purwosari agrotourism include location, transportation, promotion, fruit picking facilities, parking area, toilets, and the directions sign. Accessibility is one of elements of tourist attraction that must be developed sustainably. Accessibility is the level of tourists' convenience in transferring from one to another place including time, cost, location, and transportation. Those components are very important to lead the comfort of tourists in coming across tourist attractions. The quadrant position shows the order of priority for each attribute to increasing visitors' satisfaction and also supports the development of agrotourism. The study of Fitrianti et al. (2015) in the Harau valley tourism area reveals the priority attributes such as tourist sites, information boards, alertness, and hospitality of officers.

Quadrant II comprises attributes corresponding to the visitors' importance that should be maintained. These attributes are the taste of fruit, suitability of prices with fruit quality, the performance of the officer or guide includes friendliness, tidiness, speed, and interaction, availability of trash and attributes of worship facilities. The quality of tourism human resources plays a major role in providing services to tourists. The same results presented by Pratiwi \& Yuliawati (2019) that service attributes on Agro Hortimart such as friendliness, neatness, responsiveness have good performance is classified into quadrant II.

Quadrant III contains attributes in low priority categories such as the price of fruit, discounts, or bonuses of purchasing fruit, promotional media, and the booking procedures for large events for school or community events. Although grouped as a low priority, these attributes should not be ignored because they can enhance an increase in service performance and visitor satisfaction. The tourism manager needs to focus on the performance of each 
attribute including the position of quadrant III which has a low priority to prevent the shift of attributes toward quadrant I.

Quadrant IV is also called an excess quadrant. Consideration of these attributes is also important so that the performance that has been done is not in vain (as needed) and avoids waste both in terms of cost and resources. A research from Bismantoro et al. (2018) also found that accurate information about flora and fauna was in quadrant IV which is a quadrant that performance exceeds the Importance of visitors.

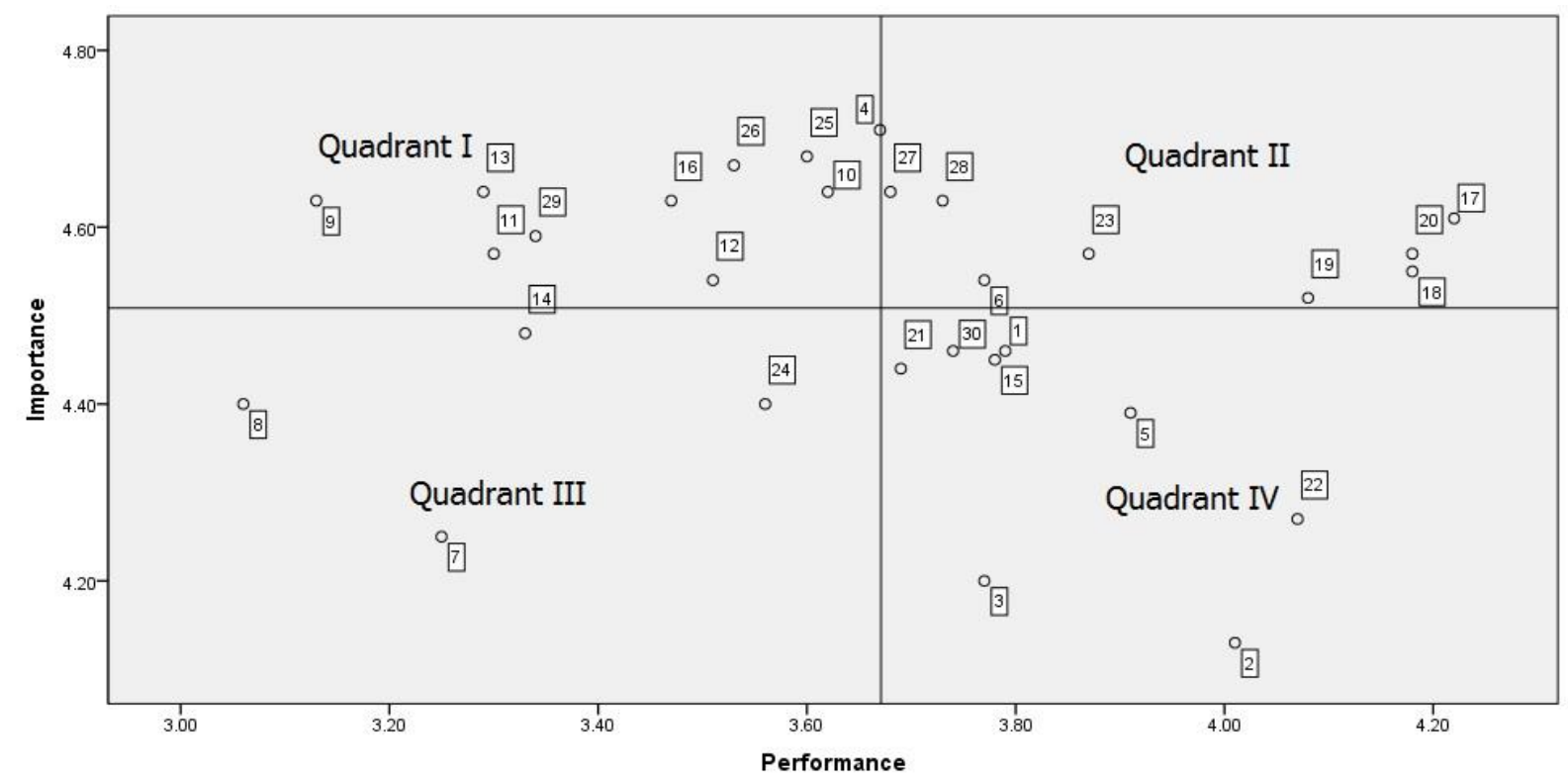

Figure 1. Cartesian diagram mapping

\section{Quadrant I (Top Priority)}

9 = Agrotourism location

$10=$ Availability of transportation

$11=$ Road conditions to the location

$12=$ Ease of reaching locations

$13=$ How promotion is carried out

$16=$ Direct fruit picking tourist facilities

$25=$ Parking space availability

$26=$ Cleanliness and comfort of the toilet

$29=$ Availability of Information board (directions board)

\section{Quadrant III (Low Priority)}

$7=$ The price of fruit is more affordable than other places

8 = Discounted price / fruit purchase bonus

$14=$ Promotional media used

24 = Ease of place booking procedures

\section{Quadrant II (Maintain Performance)}

4 = Crystal guava fruit taste

6 = Price matched with quality

$17=$ Friendliness, courtesy and tidiness of the officer / guide

$18=$ The speed and alertness of officers

$19=$ Staff interaction and knowledge

$20=$ Clarity of information

$23=$ Fruit payment (easy and fast)

$27=$ Availability of rubbish bins

$28=$ Feasibility and comfort of worship facilities

\section{Quadrant IV (Excessive)}

$1=$ Varied fruit types

2 = The size of guava fruit

3 = Texture of guava fruit

5 = Affordable fruit price

15 = Ease of getting agrotourism information

$21=$ Suitability of the tours offered

22 = Ease of entry into agrotourism procedures

$30=$ Availability of plant info boards

study, then multiplied by $100 \%$. The result shows percentage satisfaction value of 73.39 (Table 3). Ramadhani et al. (2014) stated that average visitor was categorized as satisfied with the CSI value ranging from $66-80.9 \%$. \%. Based on these figure, it divided by 5 which is the Likert scale used in the

\section{Customer Satisfaction Index (CSI)}

The value of the Total Weight Score (TWS) on CSI calculations is 3.6695 . This total score is then 
can be said that overall visitor satisfaction to all attributes in 7 variables is in the satisfied category. Field interviews also showed the results that $60 \%$ of visitors who came to agrotourism stated that they were satisfied with the experience of visiting agrotourism. The value of the Visitor Satisfaction Index in several tourist attractions such as the Aloe Vera Center Agrotourism has a CSI value of $78.54 \%$ (Prayudi et al., 2019) and the satisfaction value in Cepoko Agrotourism is $77.81 \%$ (Sembiring et al., 2020).

Table 3. The Calculations of Customer Satisfaction Index

\begin{tabular}{ccccc}
\hline $\begin{array}{c}\text { Attribute } \\
\text { Number }\end{array}$ & $\begin{array}{c}\text { Mean } \\
\text { Score of } \\
\text { Importance } \\
\text { (MSI) }\end{array}$ & $\begin{array}{c}\text { Weighting } \\
\text { Factor } \\
\text { (WF) }\end{array}$ & $\begin{array}{c}\text { Mean } \\
\text { Score of } \\
\text { Performance } \\
\text { (MSP) }\end{array}$ & $\begin{array}{c}\text { Total } \\
\text { Weight } \\
\text { Score } \\
\text { (TWS) }\end{array}$ \\
\hline 1 & 4.46 & 0.0330 & 3.79 & 0.1250 \\
2 & 4.13 & 0.0305 & 4.01 & 0.1224 \\
3 & 4.20 & 0.0311 & 3.77 & 0.1171 \\
4 & 4.71 & 0.0348 & 3.67 & 0.1278 \\
5 & 4.39 & 0.0325 & 3.91 & 0.1269 \\
6 & 4.54 & 0.0336 & 3.77 & 0.1265 \\
7 & 4.25 & 0.0314 & 3.25 & 0.1021 \\
8 & 4.40 & 0.0325 & 3.06 & 0.0995 \\
9 & 4.63 & 0.0342 & 3.13 & 0.1071 \\
10 & 4.64 & 0.0343 & 3.62 & 0.1242 \\
11 & 4.57 & 0.0338 & 3.30 & 0.1115 \\
12 & 4.54 & 0.0336 & 3.51 & 0.1178 \\
13 & 4.64 & 0.0343 & 3.29 & 0.1129 \\
14 & 4.48 & 0.0331 & 3.33 & 0.1103 \\
15 & 4.45 & 0.0329 & 3.78 & 0.1244 \\
16 & 4.63 & 0.0342 & 3.47 & 0.1188 \\
17 & 4.61 & 0.0341 & 4.22 & 0.1438 \\
18 & 4.55 & 0.0336 & 4.18 & 0.1406 \\
19 & 4.52 & 0.0334 & 4.08 & 0.1363 \\
20 & 4.57 & 0.0338 & 4.18 & 0.1412 \\
21 & 4.44 & 0.0328 & 3.69 & 0.1211 \\
22 & 4.27 & 0.0316 & 4.07 & 0.1285 \\
23 & 4.57 & 0.0338 & 3.87 & 0.1308 \\
24 & 4.40 & 0.0325 & 3.56 & 0.1158 \\
25 & 4.68 & 0.0346 & 3.60 & 0.1246 \\
26 & 4.67 & 0.0345 & 3.53 & 0.1219 \\
27 & 4.64 & 0.0343 & 3.68 & 0.1262 \\
28 & 4.63 & 0.0342 & 3.73 & 0.1277 \\
29 & 4.59 & 0.0339 & 3.34 & 0.1133 \\
30 & 4.46 & 0.0330 & 3.74 & 0.1233 \\
\hline Total & 135.26 & 1.0000 & 110.13 & 3.6695 \\
\hline & & & & \\
\hline
\end{tabular}

\section{Development Strategy Formulation}

Purwosari agrotourism development strategy is analyzed using Internal Factor Analysis Summary (IFAS) and External Factor Analysis Summary (EFAS). According to Guyana (2013), internal factors consists of strengths and weaknesses including such elements as products, sales, production, marketing, management, research, and development.
Meanwhile, external factors include outside elements in the scope of opportunity and threat such as trends, economics, demographics, technological changes, policies, competitors, social, and culture. The identification of internal factors in Purwosari agrotourism is presented in Table 4.

Table 4 shows that the main strengths of the agrotourism are the availability of attractive tourist objects and facilities such as orchards and flower gardens as well as affordable prices for fruit products and entrance tickets with a score of 0.321 . According to Priyono \& Astuti (2016), agrotourism has the main asset in attracting the interest of visitors by selling authenticity, uniqueness or characteristics, comfort, and natural beauty. Thus, natural resource factors are the main assets in developing agrotourism.

The factors indicating the weakest side of Purwosari agrotourism are promotion and the availability of information boards (directions sign) with the largest score of 0.190 and 0.189 , respectively. The promotion of Purwosari agrotourism was handled quite well although it has not been maximized. Meanwhile, the smallest score of the weakness is the relatively far location from the main road with a value of 0.121 . This is also found (Kurniasanti, 2019) in the Siam Citrus Fruit Agrotourism in which the major weakness is the absence of directions sign. This finding confirms the analysis of visitor satisfaction in which the availability of information boards or information becomes the priority attribute to be improved.

The highest score on the analysis of external factors (Table 5) on opportunities is 0.355 with a strategic factor of the agrotourism managed by the Ministry of Agriculture. It was the Ministry of Agriculture who initiated the development of the Gunungpati-Mijen area as a production center for crystal guava fruit in Semarang. This has contributed to the development of Purwosari agrotourism. According Gunawan (2016), the policy of local governments makes agrotourism areas become development areas. The next highest opportunity score is $\mathbf{0 . 3 4 0}$, exhibited by the existence of natural potential that supports the development of primary agrotourism product of crystal guava. Furthermore, the threat factor of Purwosari agrotourism is competition with surrounding attraction areas with the highest score of 0.203 . The lowest score of threat factor is the risk of the shortage of water supply in the dry season. Although the agrotourism has 
prepared well in many places to irrigate crops. However, extreme drought might affect the growth of plants and vegetation around the agrotourism area.

The formulation of Purwosari agrotourism development strategy is carried out through the determination of the position of the agrotourism based on IFAS and EFAS. Based on Tabel 4 and 5, it can be calculated how development strategy formulated. The strength and weakness factor has a score of 1.512 and 1.023 , respectively. The magnitude of the strength is greater than the weaknesses, indicating strength can overcome weaknesses (Fadlil et al., 2020). The difference between strengths and weaknesses generates an Xaxis value of 0.489 .

Table 4. The Analysis of Internal Agrotourism Factors (IFAS)

\begin{tabular}{|c|c|c|c|}
\hline Internal Factor & Weight & Rating & Score \\
\hline Strength & & & \\
\hline 1. Affordable prices for fruit products and entry tickets (free) & 0.097 & 3.300 & 0.321 \\
\hline $\begin{array}{l}\text { 2. Variety of types of fruit grown in gardens (guava, longan, passion fruit, } \\
\text { durian, soursop, orange, breadfruit) }\end{array}$ & 0.084 & 3.300 & 0.277 \\
\hline $\begin{array}{l}\text { 3. The availability of attractive tourist objects and facilities (orchards, } \\
\text { flower gardens, hydroponic greenhouses) }\end{array}$ & 0.103 & 3.100 & 0.321 \\
\hline $\begin{array}{l}\text { 4. Comfortable supporting facilities (halls, gazebos, religious facilities, } \\
\text { toilets, parking area) }\end{array}$ & 0.095 & 3.000 & 0.285 \\
\hline $\begin{array}{l}\text { 5. Have an interesting photo spot } \\
\text { Total } \\
\text { Weakness }\end{array}$ & 0.095 & 3.250 & $\begin{array}{l}0.308 \\
1.512\end{array}$ \\
\hline 1. Lack of human resources (Employees) & 0.103 & 1.550 & 0.160 \\
\hline 2. Limited number of fruits available & 0.090 & 2.050 & 0.185 \\
\hline 3. Parking space is relatively less extensive & 0.079 & 2.250 & 0.178 \\
\hline 4. Location is relatively far from the main road & 0.086 & 1.400 & 0.121 \\
\hline 5. Information boards not yet available (direction sign, parking area, etc.) & 0.084 & 2.250 & 0.189 \\
\hline $\begin{array}{l}\text { 6. Promotion has not been maximized } \\
\text { Total }\end{array}$ & 0.083 & 2.300 & $\begin{array}{l}0.190 \\
1.023\end{array}$ \\
\hline
\end{tabular}

Table 5. The Analysis of External Agrotourism Factors (EFAS)

\begin{tabular}{llll}
\hline External Factor & Weight & Rating & Score \\
\hline Opportunity & & & 0.355 \\
1. Owned and managed by the government (Ministry of Agriculture) & 0.100 & 3.550 & 0.307 \\
2. Stand side by side with other tours & 0.102 & 3.000 & 0.196 \\
3. Good access to the location (smooth road conditions, not crowded) & 0.087 & 2.250 & 0.340 \\
4. Natural potential suitable for the development of the agrotourism & 0.105 & 3.250 & 0.273 \\
5. Positive response from tourists & 0.101 & 2.700 & 0.270 \\
6. Economic improvement for the surrounding community & 0.096 & 2.800 & 1.742 \\
Total & & & 0.147 \\
Threat & & 0.092 & 1.600 \\
1. The occurrence of water shortages in the dry season & 0.064 & 3.200 & 0.203 \\
2. Competition with other attractions at adjacent area & 0.085 & 1.800 & 0.152 \\
3. Pests and diseases that can attack plants & 0.094 & 1.700 & 0.160 \\
4. The condition of the road width to the location not supported & 0.074 & 2.350 & 0.174 \\
5. Security facilities are inadequate so that more prone to stolen fruit & & 0.837 \\
Total & &
\end{tabular}

The highest score on the analysis of external factors (Table 5) on opportunities is 0.355 with a strategic factor of the agrotourism managed by the Ministry of Agriculture. It was the Ministry of Agriculture who initiated the development of the Gunungpati-Mijen area as a production center for crystal guava fruit in Semarang. This has contributed to the development of Purwosari agrotourism.
According to Gunawan (2016), the policy of local governments makes agrotourism areas become development areas. The next highest opportunity score is 0.340 , exhibited by the existence of natural potential that supports the development of primary the agrotourism product of crystal guava. Furthermore, the threat factor of Purwosari agrotourism is competition with surrounding 
attraction areas with the highest score of 0.203 . The lowest score of threat factor is the risk of the shortage of water supply in the dry season. Although the agrotourism has prepared well in many places to irrigate crops, extreme drought might affect the growth of plants and vegetation around the the agrotourism area.

The formulation of Purwosari agrotourism development strategy is carried out through the determination of the position of the agrotourism based on IFAS and EFAS. Based on Tabel 4 and 5, it can be calculated how development strategy formulated. The strength and weakness factor has a score of 1.512 and 1.023, respectively. The magnitude of the strength is greater than the weaknesses, indicating that the strength can overcome weaknesses (Fadlil et al., 2020). The difference between strengths and weaknesses generates an $\mathrm{X}$-axis value of 0.489 .

On the external factor, the score of opportunity and threat is 1.742 and 0.837 , producing a difference of 0.905 which represents the Y-ordinate number. Jatiningtias et al. (2018) stated that when the difference in the score of each factor exceeds 0 , the company is in a positive position to overcome the weaknesses or threats that exist. Thus, the difference in scores found on external and internal factors is then illustrated in the $X$ and $Y$ axes in Figure 2 .

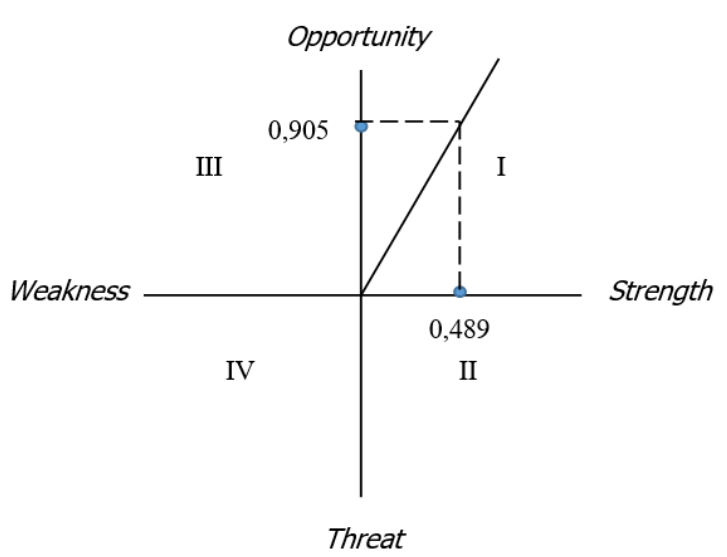

Figure 2. Agrotourism development position

Figure 2 shows that the IFAS-EFAS result of Purwosari agrotourism lays on quadrant $I$ in the diagram. It means a quadrant with fast growth and or aggressive strategies, where it maximizes strength to take advantage of as many opportunities (strength-opportunities, SO strategies). Koesomowidjojo (2017) explained that quadrant I is a perfect strategic position because it is supported by adequate resources. This result was also found in previous studies by Sembiring et al. (2020) in the Cepoko Fruit Farm agrotourism.

\section{Development Strategy and Implementation}

The results of the analysis of the SWOT matrix thoroughly produce development strategy and implementation as follows.

S-O Strategy. SO strategy is a strategy that uses factors of strengths to take advantage of opportunities (quadrant I). Based on the SWOT matrix analysis, the following are alternative strategies to develop Purwosari agrotourism. First is the innovation of tourism products. According to Swastika et al. (2017), tourism should always commit to deploying innovations every time to survive and always attract visitors. Purwosari agrotourism already produced the innovation of the product of passion fruit with a lemongrass drink called 'marreh'. Marreh is one of the most-searched drinks by the agrotourism visitors so that often runs out of stock. Purwosari agrotourism can also produce juice drinks and chips of crystal guava.

Second is cooperation with tour operators. Purwosari agrotourism occupies a strategic location and integrated into space with the position of other adjacent object attractions. The management needs to develop cooperation by offering tour packages that integrate each tourism object. The promotion in the development of the agrotourism will produce benefits in creating the main product from the characteristics of each tourism.

Third is cooperation with the supermarket. The management of Purwosari agrotourism should collaborate in partnership to open up more expansive market opportunities, especially with supermarkets. Fruit and vegetable products from Purwosari agrotourism show superior quality, this can meet the quality requirements set by supermarkets.

W-O Strategy. W-O strategy formulation is a strategy that minimizes weaknesses by utilizing opportunities. The W-O strategy emphasizes more on promotional activities as follows. First, expanding the network of cooperation with various agencies and schools. One of way to create comfort for the agrotourism visitors is to collaborate with public transportation operators to support access into agro 
locations such as feeder buses or shuttle buses. According to Utama \& Junaedi (2019), five elements should be fulfilled in the development of tourist areas, including attractions, facilities, infrastructure, transportation, and hospitality. Cooperation with schools in terms of educating agriculture is also important in the development of the agrotourism and the expansion of promotion activities.

Second is promotion using social media. Promotional activities should be carried out optimally by utilizing a variety of existing media. In addition to mouth communication, promotional activities using the internet or online media are now common, effective, and easy. Social media such as Facebook or Instagram are very helpful in promotional activities. It even can be done most simply and it is less expensive through the official website.

The third is collaborating with the community. The surrounding community can support the agrotourism management in services such as parking, farmers' markets, and security. The people who are involved do not need special qualifications to participate. A community can provide parking spaces in residents' homes when there is a big event. Besides, the community can also take part in the marketing activities of fruits and vegetable products. This is expected to have a positive impact on the economy of the surrounding community. The study (Hiryanto et al., 2017), after being involved with the management of Bejiharjo Tourism Village, the income of the people increased from one million to three million rupiahs per month

Fourth is organizing events as one of the branding efforts. Purwosari agrotourism has orchards as the main object, which is also equipped with supporting facilities to support the establishment of the agrotourism. The big size hall and a wide-open space can be used as a way to promote great events. According to Wibawanto (2015), organizing an event is one of the promotions to build an image (branding) for introducing a place. The event can lead to fulfill the objectives of tourism development, increase the number of visitors, and build public awareness and pride.

S-T Strategy. The S-T strategy is a strategy that utilizes power or strengths to deal with threats. The strategies are implemented through the following activities. First, maintain the concept and optimize tourism excellence. Since the beginning, Purwosari agrotourism has held the main concept of guava fruit-based tourism. This is in line with the opinion of Gunawan \& Wahyu (2016) that companies must have certain strategies in surviving or managing strengths so it can be leading. Long \& Nguyen (2018) also added that the natural environment is an important factor in natural tourism because it leads to characteristics of identity of a tourist attraction.

Second is involving the community in large agrotourism activities. Purwosari agrotourism is located around the residential neighborhood. Agrotourism should involve community participation in activities, especially large activities. This is a step in approaching the community so it is not to create a negative impression and to avoid social distrust. As stated by Saputra et al. (2019), the implementation of cooperation aims to achieve harmonious social conditions or avoid social turmoil.

Third is empowering the community. Based on the interviews with the Head of the Neighborhood Association, the majority of the community's work is laborers, entrepreneurs, housewives and some have main jobs as farmers. Community empowerment aims to increase the income of the surrounding community so that the community can meet a positive impact through the establishment of this agrotourism. Communities can participate in training or additional specific skills so that those with new skills can support the process of tourism management and development.

W-T Strategy. W-T strategy is also called a defensive strategy with on activities try to minimize internal weaknesses by avoiding external threats. The W-T strategy includes the following activities. First is ensuring the Standard Operating Procedure (SOP) running well. The management of Purwosari agrotourism is required to ensure SOP of cultivation of fruit plants established, and it can still produce optimally and stable. Unstable fruit production indicates a technical incompatibility between cultivation and SOP. Second is increasing the knowledge and skills of human resources. Improvements and updates on management and technology lead Purwosari agrotourism to a competitive and superior position. This requires ongoing updates including elements of human resources. Increased knowledge and skills need to be done so that there is no lagging and work objectives are achieved effectively and efficiently. The step of providing training or comparative studies is a basic thing that can be done. 


\section{CONCLUSION AND SUGGESTION}

The attributes become the main priorities for improvement Purwosari agrotourism management including location, transportation availability, road infrastructure conditions, ways to promote, directpicking fruit facilities, toilets, and availability of information boards. The satisfaction index value is in the range of satisfied categories with a percentage of $73.39 \%$. The strategy for developing Purwosari agrotourism is to use the so (strength and opportunity) strategy approach. The strategy focuses on tourism product innovation, collaboration with tour operators, and innovations to open more broadly fruit product marketing.

It is suggested that managers of the agrotourism should prioritize several attributes to improve their performance. These attributes include location, promotion and supporting facilities such as parking areas, toilets, and information boards. Managers can cooperate with the municipal transportation office in the provision of public transportation as well as increasing road access to the agrotourism.

\section{REFERENCES}

Adhanisa, C., \& Fatchiya, A. (2017). Efektivitas website dan instagram sebagai sarana promosi kawasan wisata berbasis masyarakat. Jurnal Sains Komunikasi Dan Pengembangan Masyarakat, 1(4), https://doi.org/10.29244/jskpm.1.4.451-466

Anggraeni, L. D., Deoranto, P., \& Ikasari, D. M. (2015). Analisis persepsi konsumen menggunakan metode importance performance analysis dan customer satisfaction index. Jurnal Industri, 4(2), 74-81. Retrieved from https://industria.ub.ac.id/index.php/industri/articl e/view/179

Bismantoro, D., Suryana, A. A. H., Pamungkas, W., \& Nurhayati, A. (2018). Analisis Kepuasan Wisatawan terhadap Kualitas Produk Jasa Wisata Mangrove di Desa Karangsong Kabupaten Indramayu. Perikanan Dan Kelautan, 9(2), 87-94. Retrieved from http://jurnal.unpad.ac.id/jpk/article/view/20521

Budiasa, I. W. (2011). Konsep dan potensi pengembangan agrowisata di Bali. DwijenAgro, 2(1), 1-9. Retrieved from http://ejournal.undwi.ac.id/index.php/dwijenagro/ article/view/265
Cheng, M., Jin, X., \& Wong, I. K. A. (2014). Ecotourism site in relation to tourist attitude and further behavioural changes. Current Issues in Tourism, 17(4), 303-311. https://doi.org/10.1080/13683500.2013.800030

Chin, C.-H., Law, F.-Y., Lo, M.-C., \& Ramayah, T. (2018). The impact of accessibility quality and accommodation quality on tourists' satisfaction and revisit intention to rural tourism destination in Sarawak: the moderating role of local communities' attitude. Global Business and Management Research, 10(2), 115-127. Retrieved from http://ir.unimas.my/id/eprint/22428/1/The Impact of Accessibility Quality and Accommodation Quality on Tourists' Satisfaction \%28abstract\%29.pdf

Elvera. (2020). Pemasaran Pariwisata: Kepuasan dan Loyalitas Wisatawan. PT Scopindo Media Pustaka. Retrieved from https://books.google.co.id/books?id=tMrZDwAAQ BAJ

Fadlil, M. A., Sumekar, W., \& Mardiningsih, D. (2020). Strategi pengembangan agrowisata berbasis bunga krisan (Chrysanthemum morifolium R.) di Taman Bunga Celosia, Desa Candi Kecamatan Bandungan Kabupaten Semarang. Ekonomi Pertanian Dan Agribisnis (JEPA), 4(1), 39-50. https://doi.org/10.21776/ub.jepa.2020.004.01.4

Febinanda, D. T., Pasla, P. R. Y., \& Asepta, U. Y. (2018). The effect of destination image, amenities and prices on tourists' satisfaction: a study of visitors of Jatim Park 1, Batu. Journal of Socioeconomics and Development, 1(2), 106112. https://doi.org/10.31328/jsed.v1i2.739

Fitrianti, S., Ismawati, I., \& Sillia, N. (2015). Analisis tingkat kepuasan pengunjung kawasan wisata Lembah Harau. Polibisnis, 7(1), 37-46. https://doi.org/10.1017/CBO9781107415324.004

Gunawan, G., \& Wahyu, M. (2016). Analisis strategi pengembangan agrowisata di Kampung Kramat Tanjung Desa Bunihara Kecamatan Anyer Kabupaten Serang. Jurnal Agribisnis Terpadu, 9(1), https://doi.org/10.33512/jat.v9i1.1118

Gunawan, I. M. (2016). Pengembangan agrowisata untuk kemandirian ekonomi dan pelestarian budaya di Desa Kerta, Payangan Gianyar. Jurnal Master Pariwisata (JUMPA), 3(1), 156-174. https://doi.org/10.24843/jumpa.2016.v03.i01.p11

Guyana, J. (2013). Perumusan strategi bersaing perusahaan yang bergerak dalam industri 
pelayaran. Agora, 1(3), 1115-1026. Retrieved from

http://publication.petra.ac.id/index.php/manajem en-bisnis/article/view/1067

Han, G., Akhmedov, A., Li, H., Yu, J., \& Hunter, W. C. (2020). An interpretive study on sustainability in the link between agriculture and tourism: tourist-stakeholder satisfaction in Tiantangzhai, China. Sustainability (Switzerland), 12(2). https://doi.org/10.3390/su12020571

Handayani, S. M. (2016). Agrowisata berbasis usahatani padi sawah tradisional sebagai edukasi pertanian (studi kasus desa wisata Pentingsari). Habitat, 27(3), 133-138. https://doi.org/10.21776/ub.habitat.2016.027.3.1 5

Hiryanto., Wibawa, L., \& Tohani, E. (2017). Dampak ekonomi dan sosial wisata alam berbasis masyarakat dalam konteks pemberdayaan masyarakat: studi kasus pada desa wisata Bejiharjo, Kec. Karangmojo, Kab. Gunungkidul. Jurnal Ilmu Penelitian Pendidikan, 10(2), 149160. https://doi.org/10.21831/jpipfip.v10i2.17908

Iswari, I. A. I. M., Wiranatha, A. A. P. A. S., \& Satriawan, I. K. (2015). Analisis kepuasan konsumen terhadap kualitas pelayanan dan jasa dengan menggunakan metode importance performance analysis (studi kasus di restoran warung Subak, Peguyangan Denpasar). Rekayasa Dan Manajemen Agroindustri, 3(3), 51-60. Retrieved from https://ojs.unud.ac.id/index.php/jtip/article/view/ 16925

Jatiningtias, M., Harisudin, M., \& Sundari, M. T. (2018). Strategi pemasaran agrowisata hortimart agro center Kabupaten Semarang. Agrista, 6(1), 139-149.

https://doi.org/10.1109/robot.1994.350900

Juliandi, A., Irfan, \& Manurung, S. (2014). Metodologi Penelitian Bisnis, Konsep dan Aplikasi. Medan: UMSU Press. Retrieved from https://books.google.co.id/books?id=0XrBAAAQBA]

Kementrian Pariwisata dan Ekonomi Kreatif. (2019). Laporan Akhir Kajian Dampak Sektor Pariwisata terhadap Perekonomian Indonesia. Retrieved from

https://www.kemenparekraf.go.id/index.php/post /kajian-dampak-sektor-pariwisata-terhadapperekonomian-indonesia

Koesomowidjojo, S. R. M. (2017). Balance Scorecard: Model Pengukuran Kinerja Organisasi dengan Empat Perspektif. Penebar Swadaya
Group. $\quad$ Retrieved from https://books.google.co.id/books?id=PORODwAA QBAJ

Kurniasanti, S. A. (2019). Analisis strategi pengembangan agrowisata (studi kasus kampung petani buah jeruk siam di Kecamatan BangorejoBanyuwangi). Journal of Tourism and Creativity, 3(1), 65-76. https://doi.org/10.19184/jtc.v3i1.13904

Lisarini, E., \& Ningtyas. (2014). Pengaruh bauran pemasaran $7 p$ terhadap kepuasan pelanggan di Sweetberry Agrowisata Cipanas. Agroscience, 4(2), 98-102. Retrieved from https://jurnal.unsur.ac.id/agroscience/article/view /693

Long, N. T., \& Nguyen, T. L. (2018). Sustainable development of rural tourism in an Giang Province, Vietnam. Sustainability (Switzerland), 10(4), 1-20. https://doi.org/10.3390/su10040953

Nugroho, I., Negara, P. D., \& Yuniar, H. R. (2018). The planning and the development of the ecotourism and tourism village in Indonesia: A Policy Review. Journal of Socioeconomics and Development, 1(1), 43-51. https://doi.org/10.31328/jsed.v1i1.532

Perreault, W. D., McCarthy, E. J., \& Cannon, J. P. (2006). Basic Marketing: A Marketing Strategy Planning Approach. (Pennsylvania State University, Ed.). Pennsylvania : McGraw-Hill Higher Education. Retrieved from https://books.google.co.id/books?id=KR7YAAAAM AAJ

Prasetyo, H., \& Hariani, L. (2018). Performance evaluation of the extension worker and the development strategy of organic agriculture extension in Batu City. Journal of Socioeconomics and Development, 1(2), 79-87. https://doi.org/10.31328/jsed.v1i2.594

Pratiwi, T. V., \& Yuliawati. (2019). Analisis tingkat kepuasan pengunjung terhadap kinerja dan tingkat kepentingan pengunjung pada objek wisata Agro Hortimart Agro Center Bawen, Kabupaten Semarang. Agrika, 13(1), 59-71. https://doi.org/10.31328/ja.v13i1.990

Prayudi, A. B. E. D., Dolorosa, E., \& Kurniati, D. (2019). Kepuasan pengunjung terhadap agrowisata di Agribisnis Aloe Vera Center. AGRIC, 31(1), 15-30. https://doi.org/10.24246/agric.2019.v31.i1.p1530

Priyono, A., \& Astuti, W. (2016). Pengelolaan agrowisata buah naga sebagai wisata alternatif di 
Lempongsari Sleman Yogyakarta. Kepariwisataan, 10(1), 33-42. Retrieved from http://ejournal.stipram.ac.id/index.php/kepariwisa taan/article/view/76

Ramadhani, P. D., Koestiono, D., \& Maulidah, S (2014). Analisis tingkat kepuasan konsumen terhadap kinerja pelayanan pemasok bunga potong krisan. Habitat, 25(3), 151-161. https://doi.org/10.1017/CBO9781107415324.004

Saputra, G. R., Zaenuri, M., \& Purnomo, E. P. (2019). Kemitraan pengelolaan pariwisata dalam meningkatkan pendapatan asli daerah Kabupaten Tasikmalaya Tahun 2017 (studi kasus objek wisata Gunung Galunggung Kabupaten Tasikmalaya). Kemudi: Jurnal Ilmu Pemerintahan, 03(2),

298-341. https://doi.org/10.31629/kemudi.v3i2.896

Sembiring, Y. Y. R. B., Sunarso, S., \& Roessali, W. (2020). Analisis kepuasan konsumen dan strategi pengembangan agrowisata kebun buah Cepoko di Kecamatan Gunung Pati Kota Semarang. Agrisocionomics, 4(1), 1-13. https://doi.org/10.14710/agrisocionomics.v4i1.53 78

Setiawan, R. I. (2016). Pengembangan sumber daya manusia di bidang pariwisata: perspektif potensi wisata daerah berkembang. Jurnal Penelitian
Manajemen Terapan (PENATARAN), 1(1), 23-35. Retrieved from http://journal.stieken.ac.id/index.php/penataran/ article/view/301

Swastika, I. P. D., Budhi, M. K. S., \& Dewi, M. H. U. (2017). Analisis pengembangan agrowisata untuk kesejahteraan masyarakat di Kecamatan Petang, Kabupaten Badung. E-Jurnal Ekonomi Dan Bisnis Universitas Udayana, 6(12), 4103-4136. https://doi.org/10.24843/eeb.2017.v06.i12.p03

Sznajder, M., Przezborska, L., \& Scrimgeour, F. (2009). Agritourism. Wallingford: CABI. Retrieved from https://books.google.co.id/books?id=t5YuIMs7mF QC

Utama, I. G. B. R., \& Junaedi, I. W. R. (2019). Agrowisata Sebagai Pariwisata Alternatif Indonesia: Solusi Masif Pengentasan Kemiskinan. Penerbit Deepublish. Retrieved from https://books.google.co.id/books?id=s32MDwAAQ BAJ e

Wibawanto, S. (2015). Pendekatan konseptual place marketing dan place branding dalam destination branding. Fokus Bisnis: Media Pengkajian Manajemen Dan Akuntansi, 14(2), 42-59. https://doi.org/10.32639/fokusbisnis.v14i2.47 